University of Louisville

ThinkIR: The University of Louisville's Institutional Repository

Electronic Theses and Dissertations

$12-2018$

\title{
Adolescent sexual and reproductive health in the Gambia.
}

Sandhya Lohani

University of Louisville

Follow this and additional works at: https://ir.library.louisville.edu/etd

Part of the Epidemiology Commons, and the Reproductive and Urinary Physiology Commons

\section{Recommended Citation}

Lohani, Sandhya, "Adolescent sexual and reproductive health in the Gambia." (2018). Electronic Theses and Dissertations. Paper 3108.

https://doi.org/10.18297/etd/3108

This Master's Thesis is brought to you for free and open access by ThinkIR: The University of Louisville's Institutional Repository. It has been accepted for inclusion in Electronic Theses and Dissertations by an authorized administrator of ThinkIR: The University of Louisville's Institutional Repository. This title appears here courtesy of the author, who has retained all other copyrights. For more information, please contact thinkir@louisville.edu. 
ADOLESCENT SEXUAL AND REPRODUCTIVE HEALTH IN THE GAMBIA

By

Sandhya Lohani

A Thesis submitted to the faculty of

School of Public Health and Information Sciences of the University of Louisville in Partial Fulfillment of the Requirements

for the Degree of

Master of Science in Epidemiology

Department of Epidemiology and Population Health

University of Louisville

Louisville, Kentucky

December 2018 

Sandhya Lohani

\section{A Thesis Approved on}

November 16, 2018

By the following Thesis Committee:

Thesis Committee Chair

Dr. Anne Baber Wallis

Dr. Richard N. Baumgartner

Dr. A. Scott LaJoie 


\section{ACKNOWLEDGEMENT}

This endeavor was successfully achieved and supported by a number of people. I would like to take this opportunity to thank all of them.

I would like to express my heartfelt gratitude to my thesis chair, Dr. Anne Baber Wallis for guidance, encouragement, and patience in helping me pass this critical phase successfully. I would also like to thank my committee members, Dr. Richard N. Baumgartner and Dr. Scott A. LaJoie for their comments and assistance. I am grateful to Samba Camara and Gideon Fatty for assisting me in collecting data in The Gambia. I would like to express my gratitude to the leaders, respondents, and parents in Bafuluto who helped make this study achievable.

I am grateful to my family for giving me this invaluable educational opportunity. 


\section{ABSTRACT \\ ADOLESCENT SEXUAL AND REPRODUCTIVE HEALTH IN THE GAMBIA}

Sandhya Lohani

November 16, 2018

Adolescence is a crucial period in human development. Knowledge and awareness about when to have children, when to have sex, and use of contraceptives impacts the chances of teenage pregnancy and risk of sexually transmitted diseases. The objective of this study is to determine the prevalence and associated risk factors related to age of sexual debut, teenage pregnancy, and use of contraceptives in the Gambia. This study also compares the data with 2014 survey research conducted in the Gambia. The total study population were 50 adolescents aged 13-21 years from Bafuluto and surrounding communities in the Gambia. Among 50 respondents, 40 were females and 10 were males, $58 \%$ of whom (29) report that they have had sexual intercourse in their life. Seven (24\%) reported sexual debut between 13-15 years of age. Fifteen (52\%) reported first sex between 16-18 years of age. Eight (28\%) respondents reported to have used contraceptives during their first sexual intercourse. Nine $(31 \%)$ reported to have been pregnant in their lives. When comparing data from 2018 with data from a similar study conducted in 2014, the percentage of adolescents who had sex increased by $25 \%$. In the 2014 research, none of the respondents reported having an abortion but, $3(10 \%)$ of the respondents reported having an abortion in the 2018 study. The prevalence of condom uses during last intercourse increased from 2014, $60(54 \%)$ to $50(63 \%)$ in 2018 . With regard to 
the types of contraceptives used, condoms were most frequently reported at $50 \%$ of those who reported having sex (29) in 2018, and $11 \%$ in 2014 . Only ten out of 50 respondents had attended the sexual education program conducted in 2015-16.

This study is one of the few of its kind to report on adolescent sexual behavior in West Africa. While there are limitations, including small sample size and agecohort comparisons with the 2014 study, trends noted are of concern. Due to the differences in age cohort, many of the adolescents in this study may not have attended the 2015-16 reproductive health education intervention, thus limiting comparability and conclusions about the program. 


\section{TABLE OF CONTENTS}

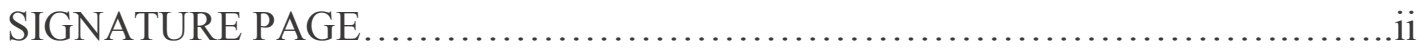

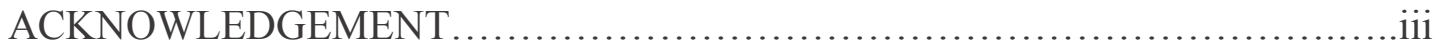

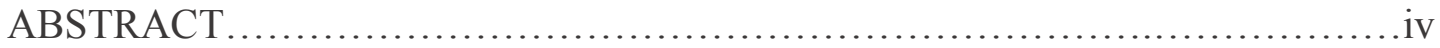

LIST OF TABLES ............................................................. viii

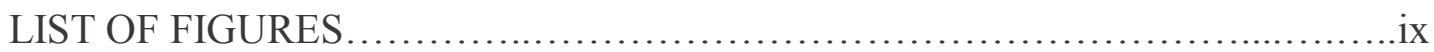

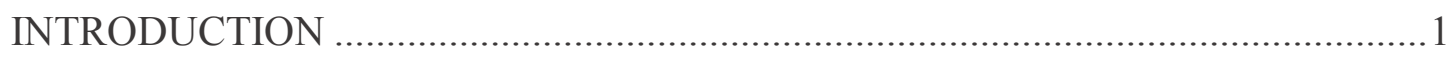

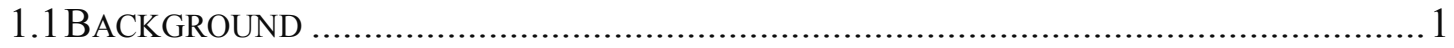

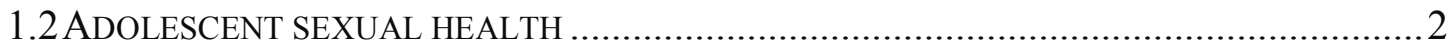

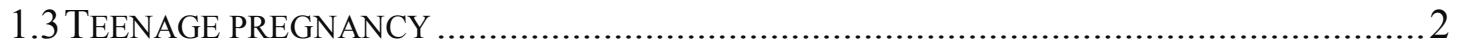

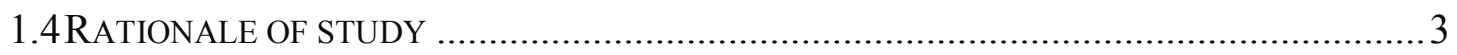

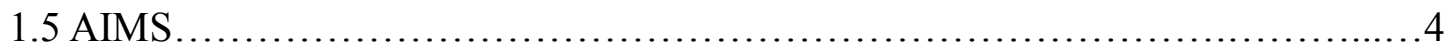

1.6 THEORETICAL FRAMEWORK ............................................

1.7 CONCEPTUAL MODEL.......................................................

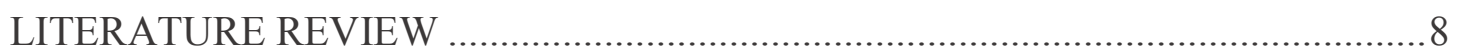

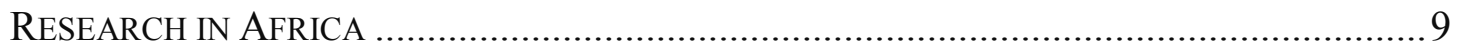

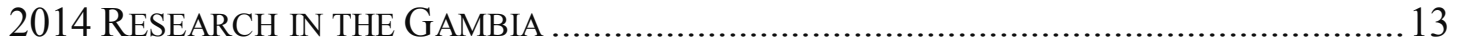

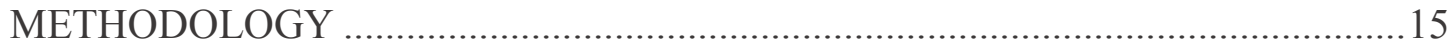

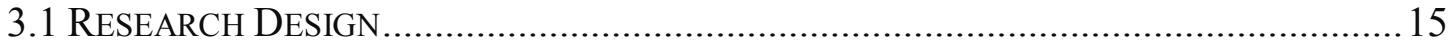

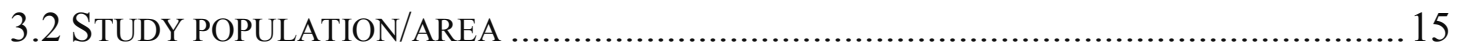

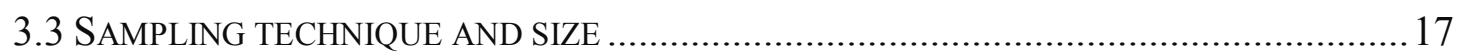

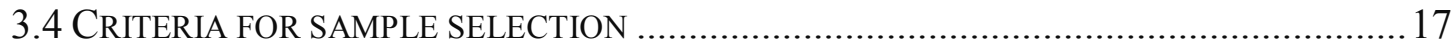

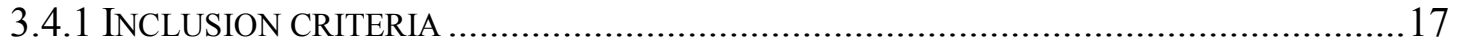




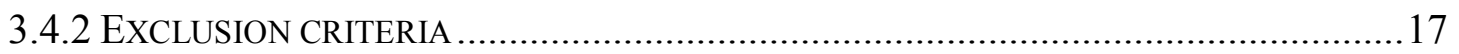

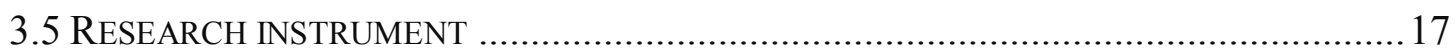

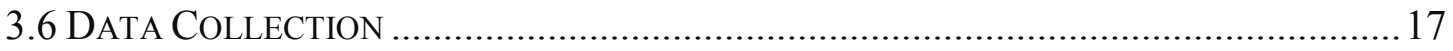

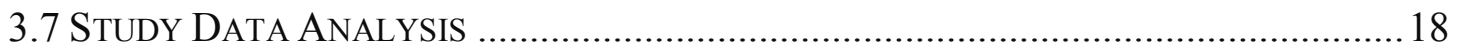

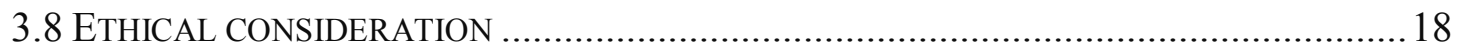

3.9 LIMITIATIONS OF THE STUDY ........................................ 18

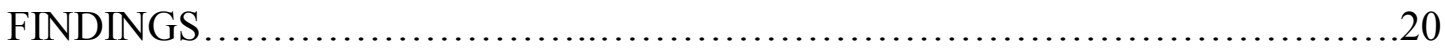

DISCUSSION AND CONCLUSION ....................................... 30

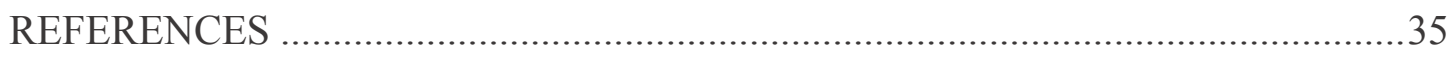

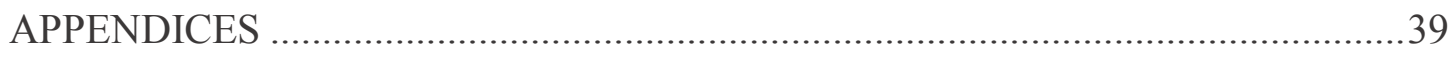

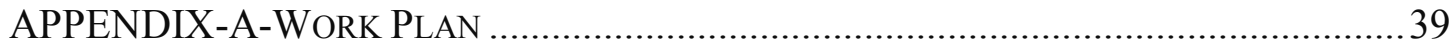

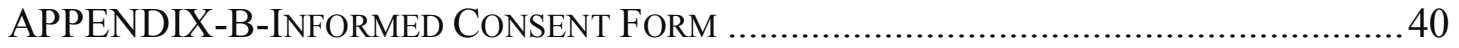

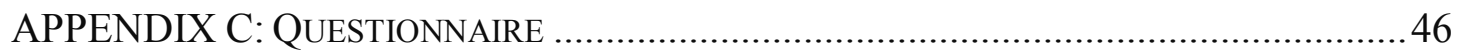

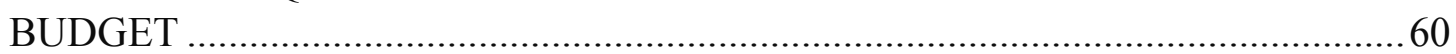

CURRICULUM VITA....................................................61 


\section{LIST OF TABLES}

TABLE

PAGE

Socio-demographic characteristics of respondents

Contraceptives use and sexual behavior among respondents reporting any sexual intercourse

Relationship information

Contraceptive information

Comparison of the findings of current study with 2014 study 


\section{LIST OF FIGURES}

FIGURE

PAGE

Conceptual framework based on socio-demographic

and behavioral variables and sexual and reproductive health

Map of The Gambia

19 


\section{INTRODUCTION}

\subsection{Background}

Adolescence is a phase of life between 10 and 21 years of age. It is considered a transitional phase of human development between childhood and adulthood during which physical, emotional and psychological changes take place (WHO, 2017). According to the American Academy of Pediatrics (AAP, 2017), adolescence is divided into three stages: early adolescence (ages 11 to 14); middle adolescence (ages 15 to 17), and late adolescence (ages 18 to 21). During these stages, a range of physical, cognitive, social and behavioral developments take place. Puberty is an important component of adolescents' physical development. Young adolescents often do not think about the consequences of their actions. The ability to make decisions and action often improves during late adolescence (AAP, 2017). Friends, peer groups and society play important roles in adolescents' social development as they want to fit in among their peers. Adolescents experience several significant changes in their development as unique individuals (AAP, 2017). Adolescents may lack the capacity to assess and comprehend complex situations, which makes them vulnerable and more likely to take the risks which may affect them long term. Biological and social transitioning also take place during adolescence. Social and cognitive processes involved in navigating complex and intimate relationships are developed during adolescence (AAP, 2017). Adolescence can be considered a time of both disorientation and discovery. Issues of 
independence, self-identity, sexuality, peer groups, romantic interests, and appearance tend to increase during adolescence (AAP, 2017).

\subsection{Adolescent sexual health}

Adolescence is a transitional stage during which rapid physical development increases along with developmental needs influenced by external factors such as peers and family. Factors that lead to the involvement of adolescents in early sexual activities include lack of education, poverty, gender inequality, lack of sex education, no discussion of sex and relationships among family members, and violence (WHO, 2017). The physical immaturity and lack of preparation for adulthood (i.e., noncompletion of basic schooling) can affect sexual decision-making among adolescents (WHO, 2017). Early sexual behavior among adolescents increases not only the risk of unwanted pregnancies among girls; it also increases the risk of contracting and transmitting Human Immunodeficiency Virus/Acquired Immunodeficiency Syndrome (HIV/AIDS) and other sexually transmitted infections. These diseases can affect longterm health, quality of life, educational aspirations, and future outcomes of adolescents.

\subsection{Teenage pregnancy}

Teenage pregnancy refers to when teenage girls, aged 13-19, become pregnant. Different factors lead to teenage pregnancy including lack of information about and access to contraception, and; socio-cultural factors like poverty, cultural acceptance of adolescent sex, child marriage, and psychological perspectives. Teenage pregnancy is a multifaceted problem that leads to many other problems such as incompletion of school, gender inequalities as young women may not fulfill their educational or professional goals, abortion, and substance abuse (WHO, 2017). The limited access to and incorrect use of contraceptives, attitudes and behaviors of health workers and 
poor access to sexual and reproductive health information put adolescents at risk of teenage pregnancy. Teenage pregnancy also contributes to maternal, infant and perinatal mortality and morbidity. Pregnant teens are less likely to get prenatal care, which puts the health of both babies and mothers at risk. It not only risks the health of the mother and child but also may lead to a cycle of poverty, especially in developing countries (WHO, 2017). The education of the girls can be compromised; their selfesteem decreases and teenage pregnancy may also increase the tendency to become involved in abusive relationship.

\subsection{Rationale of study}

Amidst the various health-related issues, teenage pregnancy remains one of the major health and social issues faced by adolescents around the world. Teenage motherhood is perceived to be a problematic issue and is related to the political, moral and economic condition of individuals, societies, and countries. A World Health Organization report published in May 2017, stated that 11\% of total births globally are to girls aged 15-19 years. These take place mostly in low and middle-income countries. The adolescent pregnancy rate in West Africa is 123 per 1000 women aged 15-19 and in The Gambia, the rate is 88 per 1000 women aged $15-19$ (UN, Department of Economic and Social Affairs, Population Division, 2015).

Pregnancy and early childbirth is one of the leading causes of deaths among adolescents aged 15-19 years (WHO, 2017). Teenage pregnancy results in wideranging consequences both for the mother and the child. There are higher risks of complications for mothers in childbirth and their infants are at greater risk of prematurity, low birth weight, death in the first year of life, and developmental problems. 
Teenage pregnancy rates differ across the world. This study focuses on The Gambia, located in the West Africa. According to the Demographic and Health Survey (DHS) conducted in The Gambia in 2013, the average age of marriage was 15 years for women, with $42 \%$ marrying before the age of 18 (GDHS, 2013). Fifteen percent of women aged 20-49 years reported having sex before the age of 15. Women's sexual debut was found to be much earlier than that of men (an average of 18.6 years for women and 23.1 years for men). Overall, the DHS reported that $24.7 \%$ of girls aged $15-19$ years had engaged in sexual intercourse (The Gambia Bureau of Statistics (GBoS) and ICF International, 2013). It has been reported that in the least developed countries, one in every four women have live births before the age of 18 (WHO, 2017). The highest proportions of early childbearing are found in subSaharan Africa, where birth rates among adolescents in some countries (eg., Mali and Niger) approach 200 births per 1000 girls aged 15-19 (WHO, 2017). According to The Gambia DHS report (2013), almost one in five (18\%) adolescent women age 15 to 19 are already mothers or pregnant with their first child.

\subsection{Aims}

- To determine the prevalence and the associated risk factors of sexual activity, age of sexual debut and use of contraceptives.

- To determine if there are differences in trends when comparing the current data findings with research conducted in 2014 in the Gambia.

\subsection{Theoretical Framework}

Adolescents' sexual behavior is of importance due to risk of increase in the initiation of early and risky sexual behaviors. Teenage and young adults may face many sexual and reproductive health risks stemming from early, unprotected, or unwanted sexual activity (AAP, 2017). Early sexual initiation increases the risk of 
unwanted pregnancies, unsafe abortions, sexually transmitted infections, and the risk of the involvement of teenagers in alcoholism and drug abuse.

Biology and genetics, individual perceptions, personality characteristics, and sociocultural norms and values are among the factors that play a role in influencing the sexual behavior of adolescents (UNFPA Gambia, 2013). Adolescent girls are mostly affected due to their involvement in early and unprotected sexual activities, which leads to unwanted pregnancy and unsafe abortion. Many young people entering their reproductive years may lack knowledge, skills and access to services they need to protect themselves (UNFPA Gambia, 2013). They are unaware of the contraceptives that can help them prevent pregnancy. Moreover, inaccessibility to effective family planning, especially in developing countries like the Gambia, increases the risk of teenage pregnancy.

In countries like The Gambia, lack of sexual and reproductive health education, information, and communication at schools, home, and communities means that; adolescents may make poor decisions in regards to sexual health, pregnancy and childbirth. The culture of non-discussion of sexuality and sexual health within families or between parents and children likely plays an important role in the incidence of early sexual debut, risky sexual behaviors, and teenage pregnancy (UNFPA Gambia, 2013).

\subsection{Conceptual Model}

The figure below is a conceptual model based on socio-demographic and behavioral variables and sexual and reproductive health. The figure shows the association of sexual and reproductive with different variables related to this study. Socio-demographic variables consist of age, sex, and lack of sex education. Behavioral variables are use of contraceptives and sexual behavior which includes involvement of adolescents in early sexual activities, and having multiple sex 
partners. Socio-demographic variables and behavioral variables are inter-connected with each other. Similarly, lack of information about contraceptives, inadequate sexual and reproductive health information, and lack of discussion about relationships/love in the family are some of the important predictors that may affect the sexual and reproductive health of adolescents. The association and how these factors affect sexual decision making for early sexual debut which leads to teenage pregnancy are explored in this study.

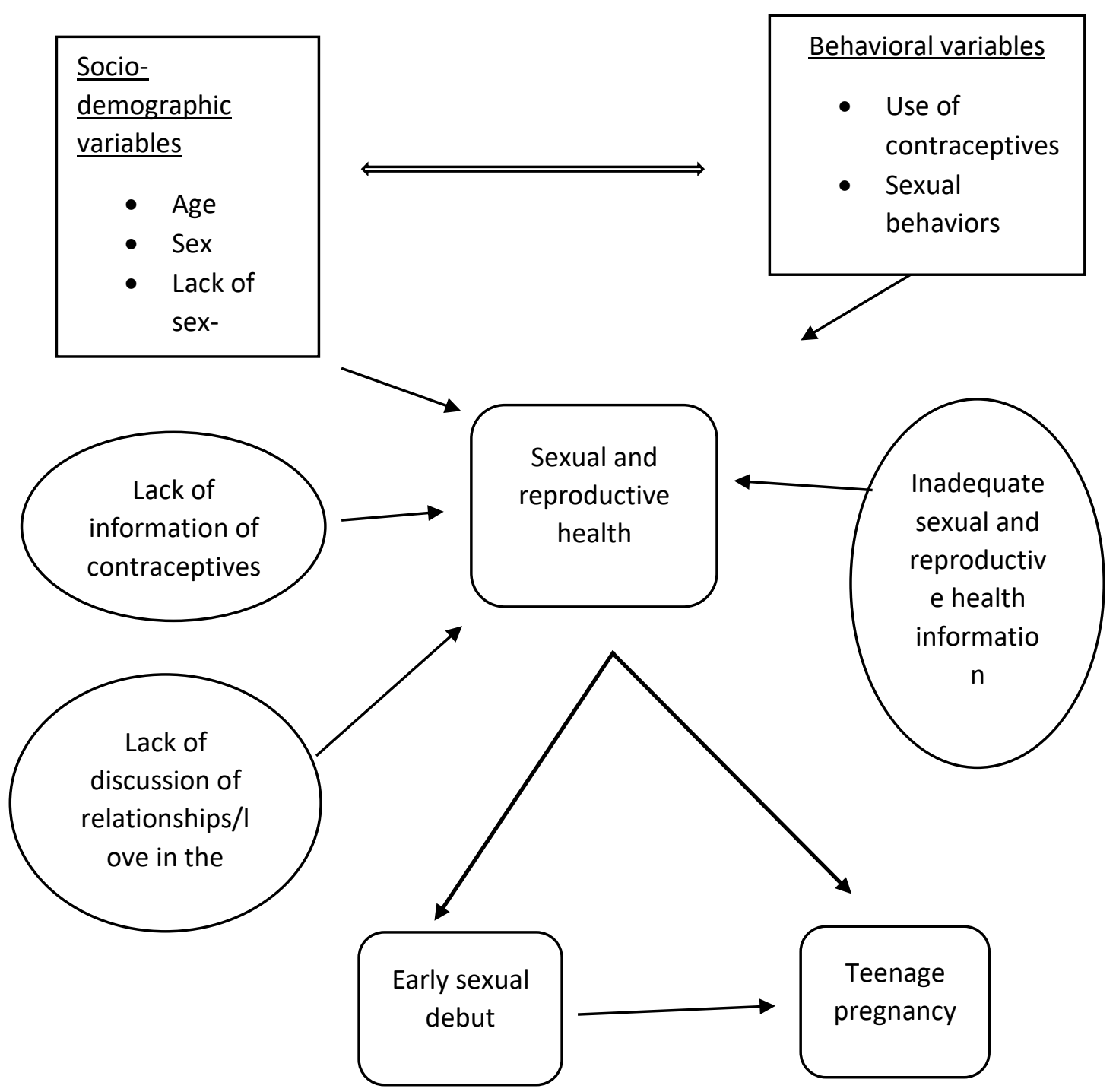


Figure 1: Conceptual framework based on socio-demographic and behavioral variables and sexual and reproductive health. 


\section{LITERATURE REVIEW}

This literature review covers the general literature on adolescent sexual health, research conducted in Africa, and the 2014 Saamasang Federation survey report on adolescent sexual and reproductive health in The Gambia.

There is evidence that adolescents' involvement in risky sexual behaviors and early sexual debut has increased with the rise in access to technologies such as the internet, television, and social media. Research conducted by Lou and colleagues (2012) found that exposure to the mass media's sexual content and pornographic videos influence adolescents and increases the risk of early sexual debut and involvement in sexual activities.

Watching sex on television has also been associated with the initiation of early sexual behavior. A national longitudinal survey conducted among 1792 adolescents aged 1217 years by the AAP in the US in 2004 reported a relationship between watching sex on television and early initiation of sexual activities among adolescents (Collins et al., 2004).

Sexual partners have an important influence on adolescents' behaviors. It is also believed that condom use is stigmatized and associated with lack of trust and gender stereotypes (Marston \& King, 2006).

Findings from a survey study conducted in Colombia among 1199 adolescents aged 1318 years in 1991, revealed that they become involved in sexual activities early in their 
lives, mainly between 15-18 years of age. Thirty-five percent of the girls and $60 \%$ of the boys were sexually active. Researchers found that they lacked knowledge of contraception and the use of contraceptives. It was also found that five percent of the girls had been pregnant, among those $66 \%$ had an abortion (Ramirez, 1991).

A cross-sectional study conducted in 2009 in the south central United States among 1736 seventh grade students on beliefs about early sex, parental support and peer behavior, found that with increase in the parents' support, there was a decrease in the odds (0.2) of believing that early sex was normal for both genders. It was found that black and Latino males and black females were more likely to believe that early sex was normal. A large proportion of females who were teenage parents or had a teenage sibling parent believed that engaging in early sex was normal ("Young adolescents' belief that early sex is normal linked to parental support and peer behavior," 2015).

\section{Research in Africa}

There is very little research on sexual behaviors in Africa and is most research is localized and may not be generalizable. Various studies have shown that early sexual debut and low use of contraceptives among adolescents is high in Africa.

A survey study in Ghana in 2003 regarding family communication about HIV/AIDS and sexual behavior among senior secondary school students, revealed that discussion of sexual and reproductive health issues with parents reduces the involvement of adolescents in risky sexual behaviors (Adu-Mireku, 2003).

A cross-sectional study conducted among 2500 in-school and 1000 out-of-school adolescents aged 10 to 19 in 2009, in Tanzania, revealed that 32\% were sexually active. Males were found more likely to be involved than females. Moreover, about $15 \%$ had 
multiple sexual partners involving males more than females. It was found that $42 \%$ used condoms inconsistently (Kazaura \& Masatu, 2009).

In a study conducted in 2017 by Accra and Kumasi in Ghana, experiences, behavior, and decision -making were three major influences found in defining young women's sexual and reproductive health. The researchers found that peers, partners and parents' interpersonal influences were both supportive and unsupportive regarding timing of sexual debut, pregnancy resolution and contraceptive use. They also found that perceived norms about acceptability of adolescents' activities and consequences like pregnancy, abortion, and childbearing were highly influenced by the community. Social and religious influences such as abstinence, teaching about premarital sex, lack of sex education, and lack of confidentiality affected adolescents' in accessibility and use of family planning methods and services (Challa et al., 2017).

The 2017 Tanzania Mainland Global School-Based Health Survey Country Report, a national study, conducted among 3,797 students ages 13-17 years, reported that sexual activities contributing to unintended pregnancy and HIV/AIDS were common. Twenty percent of all students had sexual intercourse in their life, and among those, $76.5 \%$ had their sexual debut by 14 years of age. Moreover, $5.3 \%$ of those reporting intercourse had sexual intercourse with more than two partners in their life (Nyandindi, 2017).

A qualitative study conducted in 2016 on parenting practices and styles associated with adolescents' sexual health in Dar es Salaam, Tanzania, found that parenting styleand practices were important predictors of adolescent sexual health. Parents used punitive punishment to prohibit sexual behaviors and set rules for appropriate sexual 
behaviors. They also closely monitor their adolescent children's friendship and sexual behavior (Kajula et al., 2016).

Reduced use of contraceptives is affected by limited knowledge of and access to contraceptives. In a cross-sectional study conducted by Kane and colleagues, on sexual activity and contraceptive practices among 2507 young adults aged 14-24, in Banjul, The Gambia in 1993, found that 21\% females and $7 \%$ males had used contraceptives at the time of first sexual intercourse. Females mostly used oral contraceptives and most males used condoms (Kane, De Buysscher, Taylor-Thomas, Smith, \& Jeng, 1993).

In a 2016 cross-sectional study on teenage pregnancy and other health risk behaviors in South Africa among 31816 adolescents aged 14-24, the total self-reported prevalence of those ever having been pregnant was $11 \%$. There was a decrease in sexual intercourse among adolescents in South Africa from 41.9\% in 2002 (10547) to $36.9 \%$ in 2011 (10997). However, pregnancy among girls who ever had sex increased from $17.3 \%$ in 2002 , to $23.6 \%$ in 2008 (10270) and decreased slightly to $21.3 \%$ in 2011. The odds for ever being pregnant were higher for girls who had two or more sexual partners (OR: 1.250, 95 \% CI: 1.039-1.503) (Jonas et al., 2016).

A cross-sectional study among 1140 in-school adolescents in 2002 in Nigeria found that multiple factors were associated with the sexual and reproductive health of adolescents. A self-administered questionnaire was used to assess sexual contraception, sexually transmitted diseases and fertility of adolescents. Sexual debut was found to be earlier among males $(13.9 \pm 2.8$ years $)$ than females $(14.8 \pm 2.4$ years). Males were also found to have more knowledge about contraceptives than females because of awareness about the use of condoms among males. Females $(6 \%)$ 
were found to be using contraceptives less often than males $(10.9 \%)$. This was due to the cost, unavailability of contraceptives, societal disapproval and negative attitudes about the use of contraceptives, and lack of knowledge about the use of contraceptives (Ab Rahman et al., 2011).

A cross-sectional study of 1202 in-school adolescents in Kenya on premarital sex, unwanted pregnancies/abortions and contraception conducted in 2010, found disagreement regarding premarital sex and contraception among respondents. Responses were also mixed regarding whether abortion should be allowed for pregnant school girls and some stated that a boy that impregnates a girl should be expelled from school (Adaji, Warenius, Ong'any, \& Faxelid, 2010).

\section{Conclusion}

Adolescents' sexual and reproductive health is a public health issue. Lack of knowledge and awareness about reproductive health issues, inaccessibility and lack of knowledge on the use of contraceptives have been reported to be as serious problems for adolescents in Africa. Reproductive health behaviors are affected by gender differences, social norms, religion, and traditions in Africa. Societal disapproval about the use of contraceptives, cultural taboos about contraceptives, judgmental attitudes of health care workers regarding access to contraceptives, and lack of communication about sexual and reproductive health among families are directly related to early sexual debut and teenage pregnancy. The factors and circumstances responsible for early sexual debut, teenage pregnancy, and low use of contraceptives are interconnected with the families, and societies at large. These issues need to be addressed collectively at individual, communities, national, and global levels. 


\section{Research in The Gambia}

Research conducted by the Saamasang Federation a community-based, Gambian non-governmental organization (NGO) and Child Fund International (ChildFund in The Gambia works with local NGOs like Saamasang Federation to create educational opportunities for children) assessed adolescent sexual and reproductive health among 60 adolescents ages 10-24 years in Bafuluto, Kubuneh, Galloya and Sotokoi Daru. Data from this study are reported in an informal document; thus, data from the survey is reported in percentages. The authors categorized adolescents into three age groups: 10-15, 16-20 and 21-24 years.

In the Saamasang/Child Fund study, it was found that 37\% (22) of adolescents had been in a relationship in the past year. One-third of the adolescent respondents in all age groups reported having had sexual intercourse in their lifetime. Among adolescents aged 13-15 years, 12\% (3) reported having had sexual intercourse; $33 \%$ (6) of those between 16-18 years of age reported having had sexual intercourse. And, among adolescents aged 19-21 55\% (11) reported having had sexual intercourse. The study also reported that many adolescents had sexual intercourse with more than one person. Among those 10-15 years of age, 1.9\% had sexual intercourse with more than one person. Almost 4\% of those 16-20 years of age had sexual intercourse with two people and $1.9 \%$ reported sexual intercourse with three people.

Furthermore, $1.9 \%$ of respondents between the ages of 10 and 15 years reported having had sex within the last six months. Another 59.3\% between the ages of 16 and 20 years reported having had sex within the past year. Only $9.3 \%$ of all respondents reported not having sex within the year. The study also revealed that $37 \%$ (23) of respondents approved of premarital sex and 59\% did not. Fifteen percent (9) of 
adolescents reported having had sex against their will at least once in their life. The study found that across all age cohorts, $11 \%$ (7) reported having one child and one reported having three children. Furthermore, 9\% (2) reported having been pregnant out of wedlock at least once.

Among adolescents aged 16-24 years, 9.3\% reported having been pregnant at least once, while $1.9 \%$ reported having been pregnant three times. No respondents reported having had an abortion. A total of $37 \%$ across all age groups (19) reported that they did not use condom during sexual intercourse. The study revealed that $26 \%$ (5) used contraceptives during last sexual intercourse. Among those who used contraceptives, $80 \%$ (4) used a condom, 15\% (1) reported using Depo-Provera. The study also indicated that one of the adolescents aged 10-15 years had received reproductive health information in the prior two years whereas $7.4 \%$ (3) had not received any information. Seven (11.1\%) of those 16-20 years of age received reproductive health information within the last 6 months and another seven $(3.5 \%)$ had received information within the last 7-12 months. 


\section{METHODOLOGY}

This chapter describes the research methods and materials used in study design, collecting and analyzing data needed in the study.

\subsection{Research Design}

The design of the study was analysis of coded interview data collected in The Gambia.

\subsection{Study population/area}

The study population were adolescents aged 13-21 years from Bafuluto and surrounding communities-Kubuneh, Galloya, and Sotokoi Daru in the Gambia. The map below shows The Gambia; the study communities are located about 7-10 km from Brikama

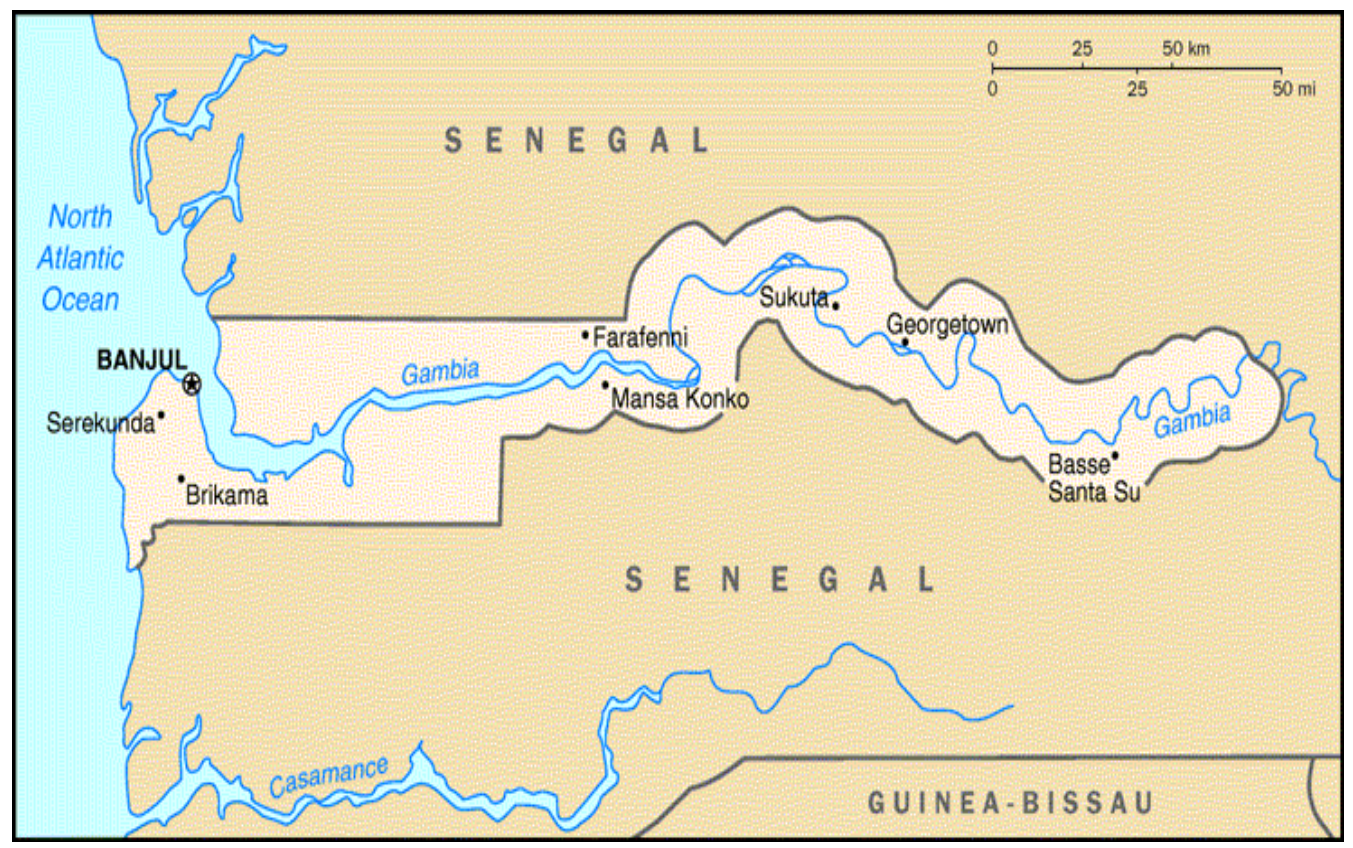


Figure 2: Map of the Gambia

The Gambia is one of the smallest countries in Africa with a population of 1.8 million and an area of 11,295 square kilometers. It is surrounded by Senegal on three sides and the Atlantic Ocean on the fourth. The Gambia is a multiethnic and multilingual country. The main ethnic groups are Mandinka, Fula, Wolof, Jola and Serahuli. English, Mandinka, Wolof, and Fula are the main languages of The Gambia. Most Gambians are Muslim and about 10\% are Christian (The Gambia Bureau of Statistics (GBoS) and ICF International, 2013). Life expectancy in The Gambia is 61 years for men 63 years for women (WHO, 2018). The country is ranked as the 175th least developed country, based on the United Nations Development Program's world human development index. Agriculture, tourism and foreign remittances are the major parts of the economy of the Gambia (Index of Economic Freedom, 2018). The infant mortality rate in The Gambia was reported by the CIA (2018) at 60.2 deaths per 1000 live births. The maternal mortality ratio was 706 per 100,000 live births (CIA, 2018). Culture and religion are major parts of life for people in the Gambia. They play vital roles in defining and determining puberty, virginity, sex, pregnancy, and childbirth. Early childbearing and high fertility tends to be higher in populations in which age at marriage is low. Early marriage not only results in an early age of sexual debut; it also increases polygyny-which is relatively common in West Africa (The Gambia Bureau of Statistics(GBoS) and ICF International, 2013).

Among the 50 municipalities in Kombo Central District, Bafuluto is one, and lies in the west coast region. According to The Gambia Bureau of Statistics 2003 and Saamasang 2015 ASP review report, fertility rates and the cases of teenage pregnancy and child marriage are higher than in other regions. Bafuluto consists of 
five wards and the total population is approximately1600 (The Gambia Bureau of Statistics (GBoS) and ICF International, 2013).

\subsection{Sampling technique and size}

The participants were selected using systematic sampling technique. This study is a small-scale study done for a limited period. The sample size was 50 adolescents taking into consideration the cost and probability of non-response.

\subsection{Criteria for sample selection}

\subsubsection{Inclusion criteria}

Inclusion criteria for the study was only those English-speaking adolescents aged between 13-21 years willing to participate in the study and available during data collection with full permission of parents for youth under 18 and living in the village of Bafuluto and surrounding communities.

\subsubsection{Exclusion criteria}

Those not willing to participate in the study or those under 18 who did not receive parental permission. Non-English speaking adolescents were excluded from the study.

\subsection{Research instrument}

A semi-structured questionnaire was used for the data collection. Questions were developed following the DHS format and the survey questions from the 2014 Saamasang/ChildFund study.

\subsection{Data Collection}

Data were collected by partners in The Gambia following approval from the University of Louisville Institutional Review Board. Data were collected through inperson interviews. First name and subject number were used as unique identifiers. After the collection of data, the data collectors stored the questionnaires and 
recordings in a locked cabinet and linked name to subject number. The names were removed and substituted with subject number only, and entered into Excel, and sent to the US author, who was responsible for analyzing the coded interview data and comparing it with the 2014 results.

\subsection{Study Data Analysis}

Data entry and analysis was done using MS Excel and SPSS version 25. Descriptive univariate and bivariate analyses was conducted. Inferential statistics were performed, as appropriate with regards to the normality of the data. Figures and tables were generated using MS Excel.

\subsection{Ethical consideration}

IRB approval was received from the Human Subjects Office at the University of Louisville. Since data were collected in The Gambia, IRB approval was also received from Saamasang Federation from the Ministry of Health and Social Welfare in The Gambia. Verbal consent was gathered from community elders prior to data collection. Written consents were gathered from participants and the parents of those adolescents under the age of 18. Interviews were conducted in private places, such as a school or in the community center. Voice recorders were used to collect data for the open-ended questions. Respondents could choose not to answer any questions if they felt uncomfortable or if the questions were overly sensitive or personal. The data were stored in a secure file with password protection. After the collection of data in The Gambia, data were scanned and sent through the author's UofL email to ensure security.

\subsection{Limitations of the study}


There is a possibility of information bias as the respondents may have given more positive information about their experiences and the intervention program. Recall bias may have occurred during the interview of the respondents. The sample size is small as the study time was limited so, results cannot be generalized to the total population of adolescents in The Gambia. 


\section{FINDINGS}

This chapter describes the analysis of data and interpretation of findings obtained from the study.

\subsection{Socio-Demographic Characteristics of Respondents}

The socio-demographic characteristics of the study sample are presented in Table 1 below. Of the total respondents, 40\% (20) were aged $19-21$ years, $40 \%$ (20) were aged 16-18 years, and 20\% (10) were between 13 and 15 years. Eighty percent (40) of the respondents were female and 10\% (10) were male. Most of the respondents were Muslim (44, 88\%) and 12\% (6) were Christians. Out of the total, 49 respondents had attended school and only one did not attend school; most (80\%) were still in school at the time of data collection. Seventy-four percent (37) of respondents had secondary (upper basic/junior/senior) education, followed by primary (lower basic) level education $(10,20 \%)$, and two were educated in Islamic traditional schools.

Table 1. Socio-Demographic Characteristics of Respondents $(\mathbf{n}=\mathbf{5 0})$

\begin{tabular}{lcc}
\hline Demographic Variables & Frequency (n) & Percent \\
\hline Age & 10 & 20 \\
$13-15$ & 20 & 40 \\
$16-18$ & 20 & 40 \\
$19-21$ & & \\
Gender & 40 & 80 \\
Female & 10 & 20 \\
Male & & \\
\hline
\end{tabular}


Tribe

Jola 15 30

Others 35 70

Religion

Muslim

44

88

Christian

6

12

Ever attended school

Yes

No

Are you in school now?

Yes 39 80

No

Highest level of school attended

Primary (lower basic)

Secondary

(upper/basic/junior/senior)

Secondary (Islamic)

\subsection{Major Findings}

The section reports on the sexual risk behavior of adolescents in this study. Overall, $58 \%$ (29) of the adolescents interviewed reported having sexual intercourse/ sexual relations with their partners.

\section{Contraceptive Use and Sexual Behavior}

Among the 29 respondents who reported having sex, seven (24\%) reported first sexual intercourse between the ages of 13-15 years, 15 (52\%) had first sex between age 16 and 18 years of age, and an additional seven (24\%) reported first sex between the ages of 19-21 years. Sixteen (55\%) respondents reported two or more sexual partners. Eight (28\%) respondents used contraceptives during the sexual intercourse, and $21(72 \%)$ did not use any contraceptives during sexual intercourse. One 
participant reported to have been paid for sexual intercourse. Six $(21 \%)$ of the respondents reported having sex against their will. Nine (31\%) of the respondents had been pregnant in their life. Out of these, six had been pregnant once in their life, and three reported being pregnant for two or more times in their life.

Among the respondents who had an abortion (3), two of them reported to have had one abortion, and one respondent reported three abortions.

Table 2. Contraceptive Use and Sexual Behavior Among Respondents Reporting Any Sexual Intercourse $(\mathbf{n}=\mathbf{2 9})$

\begin{tabular}{lll}
\hline Risky sexual behaviors & Frequency & Percent
\end{tabular}

Age at first sexual intercourse

$\begin{array}{ccc}13-15 & 7 & 24 \\ 16-18 & 15 & 52 \\ 19-21 & 7 & 24\end{array}$

Numbers of partners

1 partner 13

2 or more partners 16

Use of contraceptives during first

intercourse

Ever been paid to have sexual

intercourse

Ever had sex against will

Ever been pregnant

Number of times been pregnant

1

2 or more

Ever had abortion

Number of times had abortion
More than 3 
Attendance in Saamasang/ChildFund Sexual Education Program (2015-16)

Most (76\%) respondents reported that they had not attended any educational program about relationships, contraception, and family planning. Ten $(20 \%)$ had attended at least one component of the program; the remaining two respondents did not remember.

\subsection{Opinion on Sexual Behaviors}

Twelve percent (6) respondents responded that it is acceptable to have sex before marriage. The remaining $54(78 \%)$ said that it is not acceptable to have sex before marriage. Three $(6 \%)$ said that yes, it is acceptable to have sex before marriage, if it is with the person you will marry.

\subsection{Relationships}

The table below shows findings regarding relationship as reported in this study. Thirty-seven of the 50 respondents reported that they had been in a relationship with opposite sex. Thirty-eight percent (19) had been in a relationship with more than three people, followed by $20 \%$ of respondents (10) who had been in a relationship with two people, and four had been in a relationship with three people. The majority $(32,64 \%)$ reported that their friends are their main source of information about relationships, followed by school $(13,26 \%)$, family $(10,20 \%)$, social media $(8,16 \%)$, and one said it was the community education/sensitization program.

\section{Table 3. Relationship Information}

\begin{tabular}{lcc}
\hline Characteristics & Frequency & Percent \\
\hline Been in relationship with opposite sex & & \\
Yes & 37 & 74 \\
No & 13 & 26 \\
\hline
\end{tabular}


Number of people been in relationship with

More than 3

Sources of information about

relationships/boyfriends/girlfriends/love/emotions

(multiple choice)

Family

Friends

School

Community education/sensitization program

Television/radio

Social media (Facebook/twitter)

8

When asked about what does relationship mean to them, most of the respondents said, "It means being in friendship with someone."

"It means having boyfriends." (15-year-old-female)

Nine $(18 \%)$ of the respondents have children, and $82 \%$ do not have any children.

\subsection{Knowledge and Use of Contraceptives}

Eighty percent (40) of the respondents reported to have heard about contraceptives, but $10(20 \%)$ did not have any knowledge about contraceptives, and these were respondents ages between 13-15, all from the Jola tribe and mostly females. Among the 40 respondents who reported knowledge about contraceptives, all of them had heard about condoms, and 23 (58\%) had heard about pills. Nineteen (48\%) of these respondents said they heard about contraceptives from school and/or television/radio. Similarly, 45\% (18) reported friends/peers as their source of information about contraceptives. Eighteen percent (7) responded that the community education/sensitization program was their source, $13 \%(5)$ reported family as their source, and 5\% (2) reported health professional/doctor/nurse as their source of 
information on the contraceptives. Among the eight respondents who said they have used contraceptives, four used condoms, one used a pill and one used an emergency contraceptive method. Half of those who used contraceptives, said they got them from the health clinic, and three (38\%) from friends.

Table 4. Contraception Information $(n=50)$

\begin{tabular}{|c|c|c|}
\hline Characteristics & Frequency & Percent \\
\hline \multicolumn{3}{|l|}{ Heard about contraceptives } \\
\hline Yes & 40 & 80 \\
\hline No & 10 & 20 \\
\hline \multicolumn{3}{|c|}{ Types of contraceptives heard (multiple choice) } \\
\hline Condom & 40 & 100 \\
\hline Pills & 23 & 58 \\
\hline \multicolumn{3}{|c|}{ Learn about contraceptives (multiple choice) } \\
\hline Family & 5 & 13 \\
\hline Friends/Peers & 18 & 45 \\
\hline School & 19 & 48 \\
\hline Community education/sensitization & 7 & 18 \\
\hline Television/radio & 19 & 48 \\
\hline Health professional/doctor/nurse & 2 & 5 \\
\hline \multicolumn{3}{|c|}{ Types of contraceptives used (multiple choice) } \\
\hline Condom & 4 & 50 \\
\hline Depo-Provera & 1 & 13 \\
\hline Pills & 1 & 13 \\
\hline Emergency contraceptive pills & 1 & 13 \\
\hline \multicolumn{3}{|c|}{ Places to get contraceptives (multiple choice) } \\
\hline Health Clinic & 4 & 50 \\
\hline Friend & 3 & 38 \\
\hline
\end{tabular}

\subsection{Experiences of Intervention (sensitization)program}

Of the ten participants who reported attending the Saamasang/ChildFund sexual education program, eight said they found it useful. 
Among those who had attended the program, most of them said it was the first time they had attended a sex education program.

Comments about the program included:

"I learned about sexual and reproductive health for the first time." (16-year-old female)

"It was like I know how to prevent myself from unwanted pregnancy and plan a family. I was also trained on life skills and sexually transmitted diseases." (21-yearold female)

"I learned how to use condom before having sex." (19- year- old male)

Study participants did not think the program had brought about change among community adolescents. Some of the programs they would like to have are trainings on livelihood skills and computer skills, programs on sexual and reproductive health, early marriage, relationships, contraception, and family planning. Some of them also said that they would like to have a television program on teenage pregnancy and family planning.

It should be noted that the composition of the current study sample may include many adolescents who were too young to attend the education program in 2015-16, thus accounting for the relatively low numbers.

\section{Comparison of Current Findings with 2014 Study}

Table 5 below shows the comparison of this survey research study with the 2014 study conducted in The Gambia. Out of all(60) respondents, 37\% (22) had been in relationship in the past year in the 2014 study, whereas $68 \%$ (34) had been in relationship in the past year in 2018 research. When compared between the difference 
in the proportions, the result was found to be statistically significant (chi-square test10.393, p-value: 0.0013).

In $2014,33 \%$ (20) had sex in their life. When compared to the 2018 study, the percentage of adolescents who had sex increased by $25 \%$. The difference in the proportion was found to be statistically significant. Twelve percent (3) reported first sexual intercourse between the ages of 13-15 years, one-third (4) had first sex between 16 and 18 years of age, and 55\% (11) reported first sex between the ages of 19-21 years in 2014 research. But, in 2018 research, 24\% (7) reported first sexual intercourse between the ages of 13-15 years, 52\% (15) had first sex between 16 and 18 years of age, and $24 \%$ (7) reported first sex between the ages of $19-21$ years In the 2014 study, it was reported that $37 \%$ (23) of respondents approved of premarital sex, whereas, fewer respondents $(6,12 \%)$ reported that they approved of premarital sex in this study. Likewise, in the 2014 research, $15 \%$ (9) of the respondents reported having had sex against their will. When compared to the 2018 study, there was a decrease in the percent of adolescents $(6,12 \%)$ reporting having sex against their will. Eleven percent (7) of respondents reported to have children in 2014 whereas, $18 \%$ (9) reported to have children in 2018.

Out of respondents who had sexual intercourse, 18\% (9) reported a pregnancy in the 2018 study. This indicates an increase in $7 \%$ as compared to the 2014 study. In the 2014 research, none of the respondents reported having an abortion, but, 10\% (3) of the 2018 study respondents reported having an abortion. The prevalence of contraceptive use during last intercourse increased by $3 \%$ from 2014 to 2018 . With regards to the types of contraceptives used, condom use had the highest frequency with 50\% (4) in 2018 and $80 \%$ (4) in 2014 . This comparison was found to be statistically significant. Regarding participation in any sexual education program, 
$30 \%$ (18) reported to have had attended per the 2014 research. There has been a decrease in the respondents attending reproductive health program by ten percent as found in this study.

Analysis of the association between differences in the current findings and the 2014 study using chi-square statistics, it was found that been in relationship in the past year, age at first sexual intercourse between aged 19-21, approved of premarital sex, and types of contraceptives used were statistically significant $(p<0.05)$.

Table 5. Comparison of Current Findings with 2014 Study

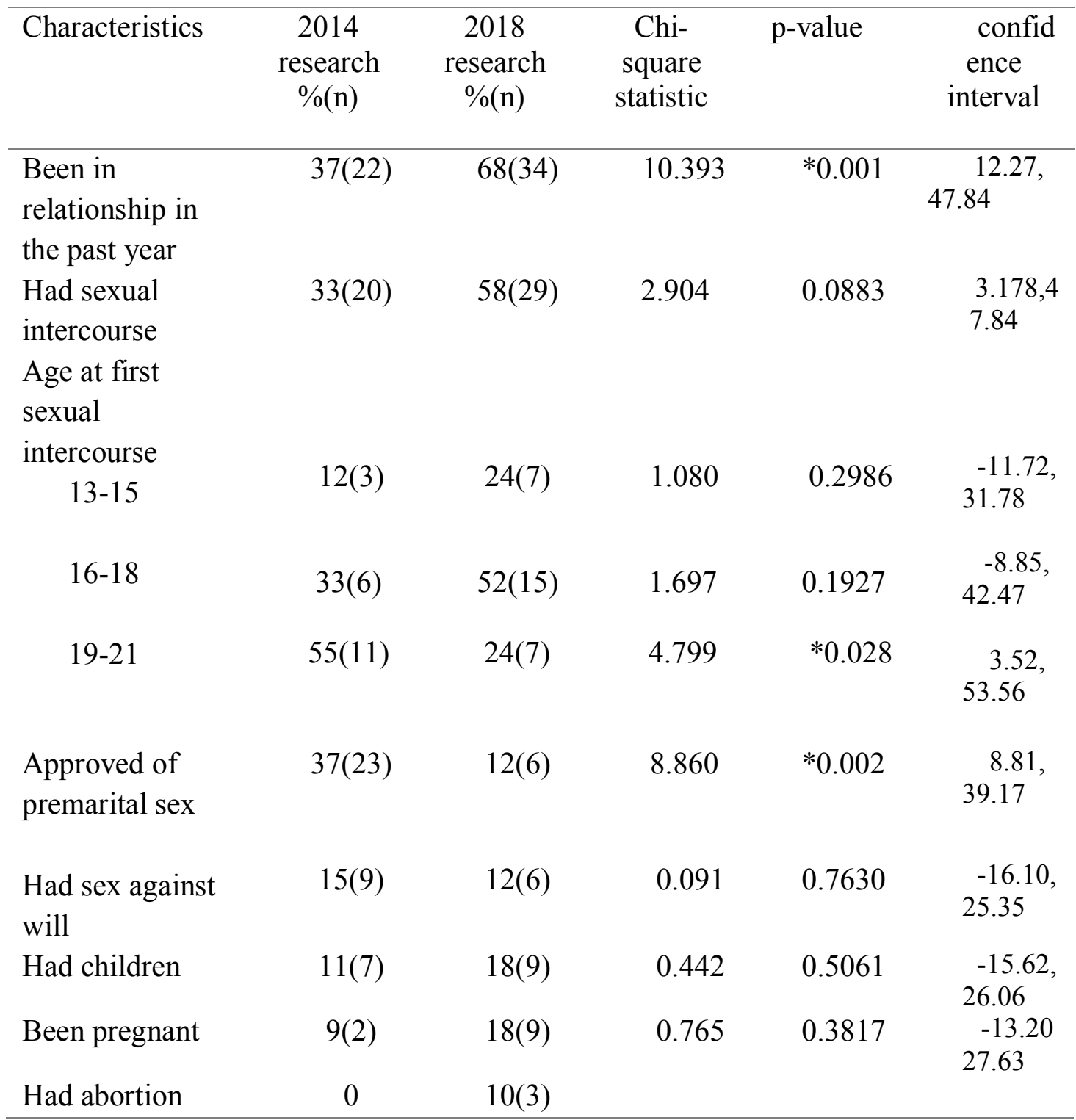




\begin{tabular}{|c|c|c|c|c|c|}
\hline $\begin{array}{l}\text { Contraceptive } \\
\text { use during last } \\
\text { sexual } \\
\text { intercourse }\end{array}$ & $26(5)$ & $28(8)$ & 0.023 & 0.8783 & $\begin{array}{l}-23.46 \text {, } \\
25.01\end{array}$ \\
\hline $\begin{array}{l}\text { Types of } \\
\text { contraceptives }\end{array}$ & & & 4.441 & $* 0.035$ & $\begin{array}{c}2.45, \\
50.05\end{array}$ \\
\hline $\begin{array}{l}\text { used } \\
\text { Condom } \\
\text { Depo- } \\
\text { Provera }\end{array}$ & $\begin{array}{l}80(4) \\
15(1)\end{array}$ & $\begin{array}{l}50(4) \\
13(1)\end{array}$ & & & \\
\hline $\begin{array}{l}\text { Participated in } \\
\text { sexual education } \\
\text { program }\end{array}$ & $30(18)$ & $20(10)$ & 1.424 & 0.2327 & $\begin{array}{c}- \\
6.49 \\
25.27\end{array}$ \\
\hline
\end{tabular}




\section{DISCUSSION AND CONCLUSION}

\section{Discussion}

Few studies have investigated reproductive and sexual beliefs and behaviors of adolescents in west Africa. This study, set in The Gambia, follows a needs assessment, conducted in 2014, that led to the launch of a sexual education program targeting adolescents in 2015-16. The primary aims of this investigation were to determine the prevalence and associated risk factors related to age of sexual debut, teenage pregnancy, and use of contraceptives in The Gambia and to determine if there are differences in trends when comparing with the current data findings from research conducted in 2014 in The Gambia. This study is important because it lends insight into possible trends in sexual behavior among adolescents in The Gambia and it provides feedback regarding the 2015-16 educational interventions established to teach young people about sex, relationships, and family planning.

More than half of the adolescents (58\%) interviewed report having had sexual intercourse, particularly in the 13-17 age group. with their partners. This finding can be compared to the 2013 DHS which reported that $15 \%$ of Gambian women age 2049 had sex before the age of 15 and $42 \%$ had sex before the age of 18 . In contrast, the 2014 Saamasang Federation/ChildFund assessment found that only about one-third reported having sex before the age of 18 . 
Teenage pregnancy was two times higher in the 2018 study as compared to 2014 . In the current research, $28 \%$ of respondents who reported having sex (28) used a contraceptive at the time of their last sexual intercourse, which represents a small increase from 2014. In 2018, among respondents who reported using contraceptives (8), half (4) said they used a condom. The Gambian DHS reported a very small increase (0.3\%) in contraceptive prevalence between 2012 and 2013 (GDHS, 2013).

It is possible that social norms and taboo, and the culture of not discussing sexuality within the family and school means that adolescents are not equipped with fundamental knowledge that might result in less sexual activity and more contraceptive use. Studies conducted in Ethiopia, Ghana, Burkina Faso, Malawi, and Uganda, found that cultural taboo, shame and lack of communication hindered discussion between parents and adolescents about matters related to sex and sexual activities (Amuyunzu-Nyamongo et al, 2005, Ayalew et al, 2014, Nove et al 2014, and Oliveira-Campos, 2014). It is also possible that the lack of communication between parents and adolescents means that teens rely more on their friends, peers, and social media, many of which may contain misleading information or encourage peers to engage in risky activities, including unprotected sex.

While this study is not fully generalizable to all of The Gambia or to west Africa as a whole, it does provide some limited evidence supporting other research that has shown an increase in teenage pregnancy among sexually active adolescents (WHO, 2017). In spite of the importance given to teenage pregnancy in the Millennium Development Goals and its direct association with the maternal mortality and morbidity, there has not been enough progress made in reducing teen pregnancy. The 
lack of other data and research on trends in teen pregnancy in The Gambia may perpetuate the situation as a public health threat.

In the present study, one person reported being paid for sex and six adolescents stated that they had sex against their will. The percentage of those reporting having unwanted sex did drop slightly from the 2014 needs assessment, but the facts remain troubling. Another important finding of this study is $10 \%$ (3) of the young women who had sex (29) reported having an abortion in their life. There were no abortions reported in the 2014 study.

\section{Limitations}

Only ten of the 50 adolescents in this study said they attended the sexual education program that was conducted in 2015-16. The evaluation of the effectiveness of sexual education program cannot be established from this study as only a few adolescents reported participating in the sexual education program. While this finding, may be disappointing to the architects of the education program, it may simply reflect the composition of the sample. Some of the adolescents interviewed may have been too young to attend in 2015-16 and similarly many of those who attended may now be over 21 and thus not eligible to have participated in this survey.

The sample size of this study is small; therefore, the study is not generalizable to the adolescents in The Gambia. Due to the small sample size, the associations between the factors under this study could not be reported.

\section{Comparisons Based on the Literature}

The current findings are similar to a survey conducted in South Africa in 2007 on predictors of condom use in South Africa among 7686 adolescents between the ages of 15-26. Condom use at sexual debut, self-efficacy, and talking with the sexual 
partners about condom use were found to be strong predictors in the study (Hendriksen, Pettifor, Lee, Coates, \& Rees, 2007). This report suggests that governmental programs and interventions to make condoms free and easily assessable to youths in health care settings has been beneficial and important.

Some researchers have suggested that poverty forces teen girls into sexual activities early in their lives (Ilika \& Igwegbe, 2004).The social structural and cultural environment is not gender neutral in The Gambia. This may affect adolescent female decision making regarding the use of contraceptives, when to have sex, and when to become pregnant.

A similar finding was reported in a 2004 study of 136 teens in rural southeast Nigeria. The authors reported that more than $75 \%$ of the girls studied reported sexual debut by 19 years, over $69 \%$ had multiple sex partners, over $95 \%$ reported having sex for money or gifts, and only 13\% had ever used condoms (Ilika \& Igwegbe, 2004).

\section{Conclusion}

The present study provides limited evidence of increases in early sexual debut, teenage pregnancy, and abortions, as compared to both the 2014 needs assessment and the 2013 DHS report. These data suggest that early sexual activity, teenage pregnancy, low contraception uptake, and abortion pose a public health threat to adolescents living in Bafuluto and surrounding communities. Although the use of contraceptives may be increasing, there is a clear need for further baseline research and for continuation of programs that address sexuality, gender equality, sexual and reproductive health, teenage pregnancy, abortion, and use of contraceptives. Regular evaluation and monitoring of the intervention programs should also be conducted.

\section{Recommendation for the future}


Studies with larger sample of adolescents should be conducted to ensure that results are representative of adolescents in The Gambia. If significant funds were available, I would recommend going to The Gambia to collect data along with research assistants. I would take interviews and I think that would be helpful in knowing the details in person compared to just analyzing data from far away. I would conduct a systematic sampling of adolescents and recruit equal numbers of male and female respondents. I would also interview the architects of the 2014 needs assessment and the 2015-16 sexual education program to learn about how it was established, what topics were included in the program, how many people attended, and other important process data. I would systematically recruit participants who had attended 2015-16 program to better evaluate the effectiveness of the program and learn about the factors that may be attributable to the program.

I would present my research findings to the stakeholders, including village representatives, the Saamasung Federation/ChildFund, and use group data collection methodology to discuss how the participation of adolescents in sexual education program can be increased and what the barriers are. I would also add some questions to the questionnaire such as; "What can be done to increase the effectiveness of educational programs?" What are the barriers to participating in programs? If I had large sample, I would conduct stratified analysis based on gender and religion on use of contraceptives and age of sexual debut. I would be able to conduct tests of association between the variables of interest, such as; having sexual intercourse and use of contraceptives, sex and age of sexual debut, and age of sexual debut and use of contraceptives so that, the results would be meaningful enough. 


\section{REFERENCES}

Ab Rahman, A., Ab Rahman, R., Ibrahim, M. I., Salleh, H., Ismail, S. B., Ali, S. H., . .. Ahmad, A. (2011). Knowledge of sexual and reproductive health among adolescents attending school in Kelantan, Malaysia. Southeast Asian J Trop Med Public Health, 42(3), 717-725.

Adaji, S. E., Warenius, L. U., Ong'any, A. A., \& Faxelid, E. A. (2010). The attitudes of Kenyan in-school adolescents toward sexual autonomy. Afr J Reprod Health, 14(1), 33-41.

Adu-Mireku, S. (2003). Family communication about HIV/AIDS and sexual behaviour among senior secondary school students in Accra, Ghana. African Health Sciences, 3(1), 7-14.

American Academy of Pediatrics. (2017). Stages of Adolescence. Retrieved from https://www.healthychildren.org/English/ages-stages/teen/Pages/Stagesof-Adolescence.aspx

Amuyunzu-Nyamongo, M., Biddlecom, A.E., Ouedraogo, C., Vanessa Woog, V. ... (2005): Qualitative Evidence on Adolescents' Views of Sexual and Reproductive Health in Sub-Saharan Africa;Occasional Report No. 16

Ayalew, M., Mengistie, B., Semahegn, A. (2014). Adolescent - parent communication on sexual and reproductive health issues among high school students in Dire Dawa, Eastern Ethiopia: a cross sectional study. Reproductive Health 2014, 11:77

Challa, S., Manu, A., Morhe, E., Dalton, V. K., Loll, D., Dozier, J., . . Hall, K. S. (2017). Multiple levels of social influence on adolescent sexual and 
reproductive health decision-making and behaviors in Ghana. Women Health, 1-17. doi:10.1080/03630242.2017.1306607

CIA, W. F. (2018). The World Factbook. Retrieved from https://www.cia.gov/library/publications/the-worldfactbook/docs/profileguide.html

Collins, R. L., Elliott, M. N., Berry, S. H., Kanouse, D. E., Kunkel, D., Hunter, S. B., \& Miu, A. (2004). Watching sex on television predicts adolescent initiation of sexual behavior. Pediatrics, 114(3), e280-289. doi:10.1542/peds.2003-1065-L Index of Economic Freedom. (2018). The

Gambia. Retrieved from http://www.heritage.org/index/country/gambia .

Hendriksen, E. S., Pettifor, A., Lee, S.-J., Coates, T. J., \& Rees, H. V. (2007). Predictors of Condom Use Among Young Adults in South Africa: The Reproductive Health and HIV Research Unit National Youth Survey. American Journal of Public Health, 97(7), 1241-1248. doi:10.2105/AJPH.2006.086009

Ilika, A., \& Igwegbe, A. (2004). Unintended pregnancy among unmarried adolescents and young women in Anambra State, south east Nigeria. Afr J Reprod Health, $8(3), 92-102$.

Jonas, K., Crutzen, R., van den Borne, B., Sewpaul, R., \& Reddy, P. (2016). Teenage pregnancy rates and associations with other health risk behaviours: a threewave cross-sectional study among South African school-going adolescents. Reprod Health, 13(1), 50. doi:10.1186/s12978-016-0170-8

Kajula, L. J., Darling, N., Kaaya, S. F., \& De Vries, H. (2016). Parenting practices and styles associated with adolescent sexual health in Dar es Salaam, Tanzania. AIDS Care, 28(11), 1467-1472.

doi:10.1080/09540121.2016.1191598. 
Kane, T. T., De Buysscher, R., Taylor-Thomas, T., Smith, T., \& Jeng, M. (1993). Sexual activity, family life education, and contraceptive practice among young adults in Banjul, The Gambia. Stud Fam Plann, 24(1), 50-61.

Kazaura, M. R., \& Masatu, M. C. (2009). Sexual practices among unmarried adolescents in Tanzania. BMC Public Health, 9, 373. doi:10.1186/1471-2458$9-373$

Lou, C., Cheng, Y., Gao, E., Zuo, X., Emerson, M. R., \& Zabin, L. S. (2012). Media's contribution to sexual knowledge, attitudes, and behaviors for adolescents and young adults in three Asian cities. J Adolesc Health, 50(3 Suppl), S26-36. doi:10.1016/j.jadohealth.2011.12.009

Marston, C., \& King, E. (2006). Factors that shape young people's sexual behaviour: a systematic review. The Lancet, 368(9547), 15811586. doi:https://doi.org/10.1016/S0140-6736(06)69662-1

Nove, A., Matthews, Z., Neal, S., Virginia, A. (2014). Maternal mortality in adolescents compared with women of other ages: evidence from 144 countries doi:10.1016/S2214-109X(13)70179-7

Nyandindi, U. S. (May 2017). Tanzania Mainland Global School-based Student Health Survey Country Report. Retrieved from The United Republic of Tanzania: http://www.who.int/chp/gshs/Tanzania_2014_GSHS_Report.pdf?ua $=1$

Oliveira-Campos, M., Nunes, M. L., Madeira,F. C., Santos, M. G., Bregmann, S. R., Malta, D. C., Giatti, L., Barreto, S. M. (2012).Sexual behavior among Brazilian adolescents, National Adolescent School-based Health Survey (PeNSE 2012). DOI: $10.1590 / 1809-4503201400050010$

Ramirez, S. (1991). Early sexual experience and traditional values in Colombia. Newsl Womens Glob Netw Reprod Rights(36), 30-31. 
Shoveller, J. A., Johnson, J. L., Langille, D. B., \& Mitchell, T. (2004). Socio-cultural influences on young people's sexual development. Social Science \& Medicine, 59(3), 473-487. doi:https://doi.org/10.1016/j.socscimed.2003.11.017

Sussex Publishers,LLC/HealthProfs.com https://www.psychologytoday.com/basics/a dolescence

The Gambia Bureau of Statistics(GBoS) and ICF International. (2013). The Gambia Demographic and Health Survey. Retrieved from The Gambia and Rockville,Maryland,USA.

The Vice President of The Republic of The Gambia launches State of the World Population

Report 2013. (2013, November 25). Retrieved from http://gambia.unfpa.org/en/news/vice-president-republic-gambialaunches-state-world-population-report-2013

The World Health Organization (WHO). Maternal, newborn, child and adolescent health. http://www.who.int/maternal_child_adolescent/topics/maternal/adolesce nt_pregnancy/en/. Accessed on 15 October 2018.

United Nations. (2015). Department of Economic and Social Affairs, Population Division. Retrieved from (https://esa.un.org/unpd/wpp/Download/Standard/Fertility/)

World Health Organization. (2017). Adolescent development. Retrieved from http://www.who.int/maternal_child_adolescent/topics/adolescence/devel opment/en/

WHO. (2018). Gambia. Retrieved from https://www.who.int/countries/gmb/en/

Young adolescents' belief that early sex is normal linked to parental support and peer behavior. (2015). Perspect Sex Reprod Health, 47(2), 109-110.

doi:10.1363/47e3915. 


\section{APPENDICES}

APPENDIX-A-Work Plan

\begin{tabular}{|c|c|c|c|c|c|c|c|c|c|}
\hline Tasks & $\begin{array}{l}\text { August- } \\
\text { Decem } \\
\text { ber } \\
2017\end{array}$ & $\begin{array}{l}\text { Ma } \\
\mathrm{y} \\
201 \\
8\end{array}$ & $\begin{array}{l}\text { Jun } \\
\mathrm{e} \\
201 \\
8\end{array}$ & $\begin{array}{l}\text { July- } \\
\text { augu } \\
\text { st } \\
2018\end{array}$ & $\begin{array}{l}\text { Septem } \\
\text { ber } \\
2018\end{array}$ & $\begin{array}{l}\text { Octob } \\
\text { er } 20, \\
2018\end{array}$ & $\begin{array}{l}\text { Octob } \\
\text { er } \\
30,20 \\
18\end{array}$ & $\begin{array}{l}\text { Novem } \\
\text { ber } \\
16,2018\end{array}$ & $\begin{array}{l}\text { Novem } \\
\text { ber } \\
27,2018\end{array}$ \\
\hline $\begin{array}{l}\text { Literatur } \\
\text { e review }\end{array}$ & & & & & & & & & \\
\hline $\begin{array}{l}\text { Preparati } \\
\text { on of } \\
\text { tools }\end{array}$ & & & & & & & & & \\
\hline $\begin{array}{l}\text { Proposal } \\
\text { submissi } \\
\text { on }\end{array}$ & & & & & & & & & \\
\hline $\begin{array}{l}\text { IRB } \\
\text { approval }\end{array}$ & & & & & & & & & \\
\hline $\begin{array}{l}\text { Data } \\
\text { collectio } \\
\text { n }\end{array}$ & & & & & & & & & \\
\hline $\begin{array}{l}\text { Data } \\
\text { entry } \\
\text { and } \\
\text { analysis }\end{array}$ & & & & & & & & & \\
\hline $\begin{array}{l}\text { Submissi } \\
\text { on of } \\
\text { draft } \\
\text { report }\end{array}$ & & & & & & & & & \\
\hline $\begin{array}{l}\text { Thesis } \\
\text { defense }\end{array}$ & & & & & & & & & \\
\hline $\begin{array}{l}\text { Submissi } \\
\text { on of } \\
\text { final } \\
\text { report }\end{array}$ & & & & & & & & & \\
\hline
\end{tabular}




\section{APPENDIX-B-Informed Consent Form}

\section{Adolescent Health in the Gambia}

Date:

You are being invited to participate in a research study by answering interviewers' questions about your knowledge and experiences on teen and young adult health. This interview will be audio recorded. This study is conducted by Sandhya Lohani, student of the Department of Epidemiology and Population Health at the University of Louisville. Dr. Anne Baber Wallis, Associate Professor at the University of Louisville is the principal investigator of this study. There are minimal risks, for your participation in this research study, which are associated with potential discomfort with some questions. The information collected may not benefit you directly. The information learned in this study may be helpful to others. The information you provide will be used for this study as a partial fulfillment of the curriculum for MS Epidemiology at the University of Louisville. Audio recordings and written records of your interview will be stored in locked office space and locked file cabinets at Saamasung Foundation offices. The interview will take approximately 30 minutes' time to complete.

Individuals from the Department of Epidemiology and Population Health, the Institutional Review Board (IRB), the Human Subjects Protection Program Office (HSPPO), and other regulatory agencies may inspect these records. In all other respects, however, the data will be held in confidence to the extent permitted by law. Should the data be published, your identity will not be disclosed.

Taking part in this study is voluntary. By answering the researcher's interview questions, you agree to take part in this research study. There is minimal risk associated 
with collection of interview data; although you may be uncomfortable with answering some questions. You do not have to answer any questions that make you uncomfortable. You may choose not to take part at all. If you decide to be in this study you may stop taking part at any time. If you decide not to be in this study or if you stop taking part at any time, you will not lose any benefits for which you may qualify. The interview will be audio recorded for open-ended questions. The previously interviewed data will also be used in this study, if you had been previously interviewed in the survey conducted in 2014 in the Gambia.

If you have any questions, concerns, or complaints about the research study, please contact: Sandhya Lohani (phone:1-502-654-4168). You can also contact Samba Camara or Gideon Fatty. They are the researchers from the Gambia.

If you have any questions about your rights as a research subject, you may call the Human Subjects Protection Program Office at (502) 852-5188. You can discuss any questions about your rights as a research subject, in private, with a member of the Institutional Review Board (IRB). You may also call this number if you have other questions about the research, and you cannot reach the research staff, or want to talk to someone else. The IRB is an independent committee made up of people from the University community, staff of the institutions, as well as people from the community not connected with these institutions. The IRB has reviewed this research study.

Sincerely,

Signature of the Investigator Signature of the Co-Investigator 


\section{SUBJECT ASSENT}

\section{Adolescent Health in the Gambia}

I am invited to be in a research study being done by Professor Dr. Anne Baber Wallis and Ms. Sandhya Lohani. When a person is in a research study, they are called a "subject". I am invited because the researcher wants to know about your knowledge and experiences on teen health. The information you provide will be used for this study as a partial fulfillment of the curriculum for Ms. Lohani's MS in Epidemiology at the University of Louisville. My completed audio recordings and written records of my interview will be stored in protected file cabinet and transcribed into a computer file with a fully protected.

This means that I will be asked some questions, which will be audio recorded. There are no wrong or right answers. There is minimal risk associated with collection of interview data; although I may be uncomfortable with answering some questions. I do not have to answer any questions that make me uncomfortable. I may choose not to take part at all. If I decide to be in this study, I may stop taking part at any time.

This interview will last for 30 minutes. If I decide not to be in this study or if I stop taking part at any time, I will not lose any benefits for which I may qualify. The interview will be audio recorded for open-ended questions. The previously interviewed data will also be used in this study, if I had been previously interviewed in the survey conducted in 2014 in the Gambia.

My family, the professor, and researcher, Sandhya Lohani, student at the Department of Epidemiology and Population Health at the University of Louisville, researchers at the Gambia, Samba Camara and Gideon Fatty will know that I'm in the study. If anyone else is given information about me, they will not know my name. 
I have been told about this study and know why it is being done and what I have to do. My parent(s) have agreed to let me be in the study. If I have any questions I can ask Samba Camara or Gideon Fatty. They will answer my questions. If I do not want to be in this study or I want to quit after I am already in this study, I can tell Samba Camara or Gideon Fatty will discuss this with my parents.

Printed Name of Parent/Guardian

Printed Name of Investigator $\quad$ Signature of Investigator $\quad$ Date Signed 


\section{PARENTAL PERMISSION DOCUMENT}

\section{Adolescent Health in the Gambia}

A research study is being conducted by Professor Anne Baber Wallis and Sandhya Lohani. The researcher wants to know about your child's knowledge and experiences on teen health. Interview will be conducted with your child and it will be audio recorded. The information provided by your child will be used for this study as a partial fulfillment of the curriculum for MS Epidemiology at the University of Louisville. The completed audio recordings and written records of the interview will be stored at private folder with the protected password.

There is minimal risk associated with collection of interview data; although your child may be uncomfortable with answering some questions. Taking part in this interview is voluntary. He/she do not have to answer any questions that make them uncomfortable. $\mathrm{He} / \mathrm{she}$ may choose not to take part at all. If he/she decide to be in this study, he/she may stop taking part at any time.

This interview will last for 30 minutes. Your child may not get direct benefit from this study. However, the results of this study will be helpful in the future. The previously interviewed data will also be used in this study, if he/she had been previously interviewed in the survey conducted in 2014 in the Gambia.

Your family, the professor, and researcher, Sandhya Lohani, student at the Department of Epidemiology and Population Health at the University of Louisville, researchers at the Gambia, Samba Camara and Gideon Fatty will know that he/she is in the study.

If you have any questions you can ask Samba Camara or Gideon Fatty. They will answer your questions. Please read the section below and check one box. 
I have read this form and know what the interview is about.

Check one:

[ ] My child may take part in this interview.

[ ] My child may not take part in this interview.

Printed Name of Parent/Guardian

Printed Name of Investigator

Signature of Investigator

Date Signed 
Name of Interviewer:

Setting: Home/Community center/ School/Other:

GPS position:

Time started: Time ended:

Introduction: Hello, my name is [ ]. I am from

UTG/Saamasang/Child Fund/other. We are conducting a survey to learn about teen and young adult health. I would like to ask questions about age, relationships, health, contraception, and other details. This interview will take about 30 minutes. All the information I obtain will remain fully confidential and your responses will never be identified. You may choose to NOT respond to any question you do not want to answer or that makes you feel uncomfortable. If you are 21 or younger, I would like to speak to you. The data analysis of this study will be done by the student at University of Louisville, USA and she will not share the information outside her department.

Do you have any questions?

Do you agree to being interviewed? YES/NO

If YES, signature: 


\begin{tabular}{|c|c|c|}
\hline \multicolumn{3}{|c|}{ A. Demographic characteristics } \\
\hline 1 . & $\begin{array}{l}\text { What is your relationship to the head of } \\
\text { household/compound? }\end{array}$ & $\begin{array}{l}\text { a. Wife } \\
\text { b. Daughter } \\
\text { c. Son } \\
\text { d. Brother/Sister } \\
\text { e. Nephew/Niece } \\
\text { f. Other (please specify.) } \\
\text { Don't know..................98 } \\
\text { Refuse to answer............99 }\end{array}$ \\
\hline 2. & Age & \\
\hline 3. & Gender & \\
\hline 4. & What is your tribe/ethnicity? & $\begin{array}{l}\text { a. Mandinka } \\
\text { b. Wollof } \\
\text { c. Jola } \\
\text { d. Fula } \\
\text { e. Serere } \\
\text { f. Serahule } \\
\text { g. Creole } \\
\text { h. Other (please specify...) } \\
\text { Don't know................98 } \\
\text { Refuse to answer..........99 }\end{array}$ \\
\hline 5. & Are you married? & $\begin{array}{l}\text { a. Yes } \\
\text { b. No }\end{array}$ \\
\hline
\end{tabular}




\begin{tabular}{|c|c|c|}
\hline 6. & What is your nationality? & $\begin{array}{l}\text { a. Gambian } \\
\text { b. Non-Gambian }\end{array}$ \\
\hline 7. & What is your religion? & $\begin{array}{l}\text { a. Muslim } \\
\text { b. Christian } \\
\text { c. Other religion } \\
\text { d. No religion } \\
\text { Don't know...............998 } \\
\text { Refuse to answer..........99 }\end{array}$ \\
\hline B. & Education & \\
\hline 8. & Have you ever attended school? & $\begin{array}{l}\text { a. Yes } \\
\text { b. No }\end{array}$ \\
\hline 9. & Are you in school now? & $\begin{array}{l}\text { a. Yes } \\
\text { b. No }\end{array}$ \\
\hline 10. & If yes, what grade are you in? & \\
\hline 11. & $\begin{array}{l}\text { What is the highest level of school you } \\
\text { have attended? }\end{array}$ & $\begin{array}{l}\text { a. Preschool } \\
\text { b. Primary (lower basic) } \\
\text { c. Primary (Islamic) } \\
\text { d. Secondary (upper } \\
\text { basic/junior/senior) } \\
\text { e. Secondary (Islamic) } \\
\text { f. Higher (tertiary, college, } \\
\text { university) } \\
\text { Don't know...............99 } \\
\text { Refuse to answer.........99 }\end{array}$ \\
\hline
\end{tabular}




\begin{tabular}{|c|c|c|}
\hline C. & Relationships & \\
\hline 12. & $\begin{array}{l}\text { What does being in a relationship mean } \\
\text { to you? Please explain. }\end{array}$ & \\
\hline 13. & $\begin{array}{l}\text { Have you ever been in a relationship with } \\
\text { a member of the opposite sex? }\end{array}$ & $\begin{array}{l}\text { a. Yes } \\
\text { b. No }\end{array}$ \\
\hline 14. & $\begin{array}{l}\text { Have you ever been in a relationship with } \\
\text { a member of the same sex? }\end{array}$ & $\begin{array}{l}\text { a. Yes } \\
\text { b. No }\end{array}$ \\
\hline 15. & $\begin{array}{l}\text { How many people have you been in a } \\
\text { relationship with in your life? }\end{array}$ & $\begin{array}{l}\text { a. } 0 \\
\text { b. } 1 \\
\text { c. } 2 \\
\text { d. } 3 \\
\text { e. } 4 \\
\text { f. } 5 \\
\text { g. More than } 5\end{array}$ \\
\hline 16. & $\begin{array}{l}\text { Have you been in a relationship in the } \\
\text { past year? }\end{array}$ & $\begin{array}{l}\text { a. Yes } \\
\text { b. No }\end{array}$ \\
\hline
\end{tabular}




\begin{tabular}{|c|c|c|}
\hline 17. & $\begin{array}{l}\text { What are your sources of information } \\
\text { about relationships /boyfriends- } \\
\text { girlfriends/love/emotions? }\end{array}$ & $\begin{array}{l}\text { Select all that apply } \\
\text { a. Family } \\
\text { b. Friends } \\
\text { c. School } \\
\text { d. Community } \\
\text { education/sensitization } \\
\text { program } \\
\text { e. Television/radio } \\
\text { f. Social media } \\
\text { /internet(Facebook/twitt } \\
\text { er) } \\
\text { g. Others (please specify) } \\
\text { Don't know...............98 } \\
\text { Refuse to answer..........99 }\end{array}$ \\
\hline 18. & $\begin{array}{l}\text { In your opinion, at what age is a girl old } \\
\text { enough to get married? }\end{array}$ & Age: \\
\hline 19. & $\begin{array}{l}\text { In your opinion, at what age is a boy old } \\
\text { enough to get married? }\end{array}$ & Age: \\
\hline 20. & $\begin{array}{l}\text { At what age, do you expect to be } \\
\text { married? }\end{array}$ & Age: \\
\hline D. & Knowledge and experience of sex & \\
\hline
\end{tabular}




\begin{tabular}{|c|c|c|}
\hline 21. & $\begin{array}{l}\text { Have you had an intimate contact (eg: } \\
\text { hugging/kissing/touching) with your } \\
\text { girlfriends/boyfriends? }\end{array}$ & $\begin{array}{l}\text { a. Yes } \\
\text { b. No }\end{array}$ \\
\hline 22. & $\begin{array}{l}\text { Have you had sexual intercourse/sexual } \\
\text { relations with them? }\end{array}$ & $\begin{array}{l}\text { a. Yes } \\
\text { b. No }\end{array}$ \\
\hline 23. & $\begin{array}{l}\text { If yes, when did you have sexual } \\
\text { intercourse for the first time? }\end{array}$ & Age: \\
\hline 24. & $\begin{array}{l}\text { How many persons have you had sexual } \\
\text { intercourse with? }\end{array}$ & $\begin{array}{l}\text { a. } 1 \\
\text { b. } 2 \\
\text { c. } 3 \\
\text { d. } 4 \\
\text { e. } 5 \\
\text { f. } 5 \text { or more } \\
\text { Refuse to answer...........99 }\end{array}$ \\
\hline 25. & $\begin{array}{l}\text { When did you last have sexual } \\
\text { intercourse? }\end{array}$ & \\
\hline 26. & $\begin{array}{l}\text { The last time you had sexual intercourse, } \\
\text { did you use any method of } \\
\text { contraception? }\end{array}$ & $\begin{array}{l}\text { a. Yes } \\
\text { b. No }\end{array}$ \\
\hline
\end{tabular}




\begin{tabular}{|c|c|c|}
\hline 27. & If yes, what type did you use? & $\begin{array}{l}\text { Select all that apply: } \\
\text { a. Condom } \\
\text { b. Injection } \\
\text { c. IUD } \\
\text { d. Pill } \\
\text { e. Other (please specify.) } \\
\text { Don't know..............98 } \\
\text { Refuse to answer.........99 }\end{array}$ \\
\hline 28. & $\begin{array}{l}\text { How many people have you had sexual } \\
\text { intercourse with in the past year? }\end{array}$ & $\begin{array}{l}\text { a. } 1 \\
\text { b. } 2 \\
\text { c. } 3 \\
\text { d. } 4 \\
\text { e. } 5 \\
\text { f. } \text { More than } 5 \\
\text { Refuse to answer...........99 }\end{array}$ \\
\hline 29. & $\begin{array}{l}\text { Has anyone ever paid you to have sex } \\
\text { with them? (Payment could be money, } \\
\text { gifts, favors) }\end{array}$ & $\begin{array}{l}\text { a. Yes } \\
\text { b. No }\end{array}$ \\
\hline 30. & $\begin{array}{l}\text { Have you ever paid anyone to have sex } \\
\text { with you? (Payment could be money, } \\
\text { gifts, favors) }\end{array}$ & $\begin{array}{l}\text { a. Yes } \\
\text { b. No }\end{array}$ \\
\hline 31. & $\begin{array}{l}\text { When do you think, a person is old } \\
\text { enough to have sexual intercourse? }\end{array}$ & Age: \\
\hline
\end{tabular}




\begin{tabular}{|c|c|c|}
\hline 32. & $\begin{array}{l}\text { Do you think it is OK to have sex before } \\
\text { you are married? }\end{array}$ & $\begin{array}{l}\text { a. Yes, it is ok } \\
\text { b. Yes, but only if it is } \\
\text { with the person you will } \\
\text { marry } \\
\text { c. No } \\
\text { Don't know.................98 } \\
\text { Refuse to answer............99 }\end{array}$ \\
\hline 33. & $\begin{array}{l}\text { Have you made a pledge to abstain from } \\
\text { sex until you are married? }\end{array}$ & $\begin{array}{l}\text { a. Yes } \\
\text { b. No } \\
\text { Don't know.............98 } \\
\text { Refuse to answer.........99 }\end{array}$ \\
\hline 34. & Have you ever had sex against your will? & $\begin{array}{l}\text { a. Yes } \\
\text { b. No } \\
\text { Don't know.............998 } \\
\text { Refuse to answer.........99 }\end{array}$ \\
\hline 35. & $\begin{array}{l}\text { If yes, how many times have you have } \\
\text { sex against your will? }\end{array}$ & $\begin{array}{l}\text { a. } 1 \\
\text { b. } 2 \\
\text { c. } 3 \\
\text { d. More than } 3\end{array}$ \\
\hline E. & Teenage Pregnancy and abortion & \\
\hline 36. & Are you pregnant now? & $\begin{array}{l}\text { a. Yes } \\
\text { b. No } \\
\text { Don't know.............98 } \\
\text { Refuse to answer.........999 }\end{array}$ \\
\hline
\end{tabular}




\begin{tabular}{|c|c|c|}
\hline 37. & $\begin{array}{l}\text { (If female), when was the first day of } \\
\text { your last period? }\end{array}$ & Month/Day: \\
\hline 38. & Have you ever been pregnant? & $\begin{array}{l}\text { a. Yes } \\
\text { b. No } \\
\text { Refuse to answer..........99 }\end{array}$ \\
\hline 39. & $\begin{array}{l}\text { If yes, how many times have you been } \\
\text { pregnant? }\end{array}$ & $\begin{array}{l}\text { a. } 1 \\
\text { b. } 2 \\
\text { c. } 3 \\
\text { d. } 4 \\
\text { e. More than } 4\end{array}$ \\
\hline 40. & $\begin{array}{l}\text { Did you end your pregnancy } \\
\text { intentionally? }\end{array}$ & $\begin{array}{l}\text { a. Yes } \\
\text { b. No } \\
\text { Don't know .............98 } \\
\text { Refuse to answer..........99 }\end{array}$ \\
\hline 41. & If yes, how many times? & $\begin{array}{l}\text { a. } 1 \\
\text { b. } 2 \\
\text { c. } 3 \\
\text { d. More than } 3 \\
\text { Refuse to answer.........99 }\end{array}$ \\
\hline
\end{tabular}




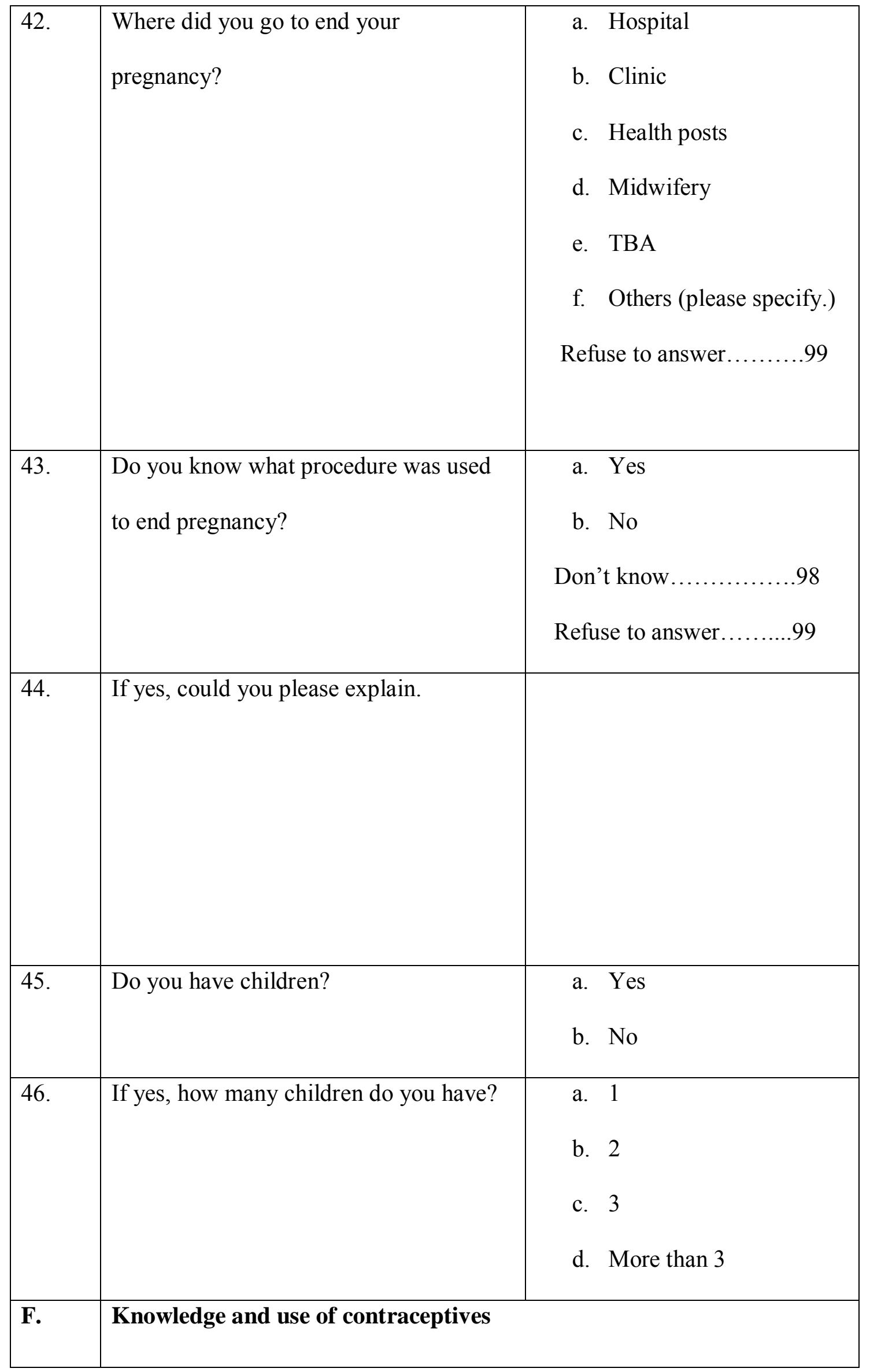




\begin{tabular}{|c|c|c|}
\hline 47. & Have you heard about contraceptives & $\begin{array}{l}\text { a. Yes } \\
\text { b. No } \\
\text { Don't know.................98 }\end{array}$ \\
\hline 48. & $\begin{array}{l}\text { If yes, please name the types of } \\
\text { contraceptives you have heard about. }\end{array}$ & $\begin{array}{l}\text { Select all that apply: } \\
\text { a. Condom } \\
\text { b. Depo-Provera } \\
\text { c. Pills } \\
\text { d. Emergency } \\
\text { contraceptive pills } \\
\text { e. Diaphragm } \\
\text { f. Implants } \\
\text { g. Foam/jelly } \\
\text { h. Breastfeeding } \\
\text { i. Rhythm method } \\
\text { j. Withdrawal method } \\
\text { k. Traditional method } \\
\text { 1. Other (please specify.) }\end{array}$ \\
\hline
\end{tabular}




\begin{tabular}{|c|c|c|}
\hline 49. & $\begin{array}{l}\text { How did you learn about family } \\
\text { planning/contraceptives? }\end{array}$ & $\begin{array}{l}\text { Select all that apply: } \\
\text { a. Family } \\
\text { b. Friends/peers } \\
\text { c. School } \\
\text { d. Community } \\
\text { education/sensitization } \\
\text { e. Television/radio } \\
\text { f. Health } \\
\text { professionals/doctor/nur } \\
\text { g. Health clinic } \\
\text { h. Social media (Facebook } \\
\text { i. Otwitter) }\end{array}$ \\
\hline 50. & $\begin{array}{l}\text { Have you ever done something to prevent } \\
\text { pregnancy? }\end{array}$ & $\begin{array}{l}\text { a. Yes } \\
\text { b. No }\end{array}$ \\
\hline
\end{tabular}




\begin{tabular}{|c|c|c|}
\hline 51. & If yes, what method have you used? & $\begin{array}{l}\text { Select all that apply: } \\
\text { a. Condom } \\
\text { b. Depo-Provera } \\
\text { c. Pills } \\
\text { d. Emergency } \\
\text { e. Diaphragm } \\
\text { f. Implants } \\
\text { g. Foam/jelly } \\
\text { h. Breastfeeding } \\
\text { i. Rhythm method } \\
\text { j. Withdrawal method } \\
\text { k. Traditional method } \\
\text { 1. Other (please specify) }\end{array}$ \\
\hline 52. & $\begin{array}{l}\text { Where have you gone to get one of these } \\
\text { contraceptives? }\end{array}$ & $\begin{array}{l}\text { Select all that apply: } \\
\text { a. Health clinic } \\
\text { b. Shop } \\
\text { c. Friend } \\
\text { d. Parent } \\
\text { Don't know ...........98 }\end{array}$ \\
\hline 53. & $\begin{array}{l}\text { Are you currently using any } \\
\text { contraceptives? }\end{array}$ & $\begin{array}{l}\text { a. Yes } \\
\text { b. No }\end{array}$ \\
\hline 54. & $\begin{array}{l}\text { If yes, why do you think you need to use } \\
\text { contraceptives? }\end{array}$ & \\
\hline
\end{tabular}




\begin{tabular}{|c|c|c|}
\hline G. & Experiences of Intervention (sensitizati & orogram \\
\hline 55. & $\begin{array}{l}\text { Have you attended any sensitization } \\
\text { program about relationships, } \\
\text { contraception, and family planning? }\end{array}$ & $\begin{array}{l}\text { a. Yes } \\
\text { b. No } \\
\text { c. I don't remember }\end{array}$ \\
\hline 56. & $\begin{array}{l}\text { If yes, can you please tell me what that } \\
\text { experience was like? }\end{array}$ & \\
\hline 57. & $\begin{array}{l}\text { If yes, what did you learn from the } \\
\text { program? }\end{array}$ & \\
\hline 59. & How was it useful for you? & $\begin{array}{l}\text { a. Yes } \\
\text { b. No } \\
\text { c. I don't know }\end{array}$ \\
\hline 60. & $\begin{array}{l}\text { Do you think the program has brought } \\
\text { changes among the adolescents in your } \\
\text { community? }\end{array}$ & \\
\hline 61. & If yes, what changes have you observed? & \\
\hline 62. & $\begin{array}{l}\text { What other kinds of programs do you } \\
\text { think would be useful for youth in the }\end{array}$ & \\
\hline
\end{tabular}




\begin{tabular}{|l|l|l|}
\hline & community? & \\
\hline
\end{tabular}

\section{BUDGET}

The table below indicates the budget allocated for the different items with the cost that will be required for this study. I have funded this study.

\begin{tabular}{|l|l|}
\hline ITEMS & ALLOCATED COST \\
\hline Interviewees & $\$ 100$ \\
\hline Coordinator & $\$ 100$ \\
\hline Communication & $\$ 20$ \\
\hline Printing and stationary in The Gambia & $\$ 80$ \\
\hline Scan & $\$ 100$ \\
\hline Printing/binding report & $\$ 50$ \\
\hline TOTAL & $\$ 450$ \\
\hline
\end{tabular}




\section{CURRICULUM VITA}

Sandhya Lohani, MS Epidemiology

1. Academic Qualifications:

- M.S Epidemiology: University of Louisville, Kentucky. (December 2018)

- Post Graduate Diploma in Women's Studies in Distinction (79.5\%)from Padma Kanya Campus, Tribhuvan University, Nepal in 2014. (Gold medalist)

- Bachelors in Public Health (BPH) in first division (77\%) from National Academy for Medical Sciences, Purbanchal University, Nepal in 2012.

2. Work experiences:

A) Research and Administrative Assistant at University of Louisville

Division of Infectious Disease, Louisville, Kentucky. May 2017-Present

B) Research Assistant at John Hopkins Bloomberg

2015-2016

School of Public Health, Baltimore, USA on Public

Health Research conducted by PhD student in Nepal.

C) Research Assistant at Research Input and Development

2013-2015 Action (RIDA):

- "The Big Ideas Dahi Project" by Research Inputs and Development Action (RIDA) as implementing partner and commissioned by UC Berkeley, Texas A\&M University, Purdue University.

- Monitoring and Evaluation of Support to Education of Marginalized Girls in Kailali" (STEM) commissioned by RIDA and MERCY CORPS International.

- "Creative Theme Testing for Behaviour Change Communication" (BCC) materials developed for Bhanchhin Aaama Campaign commissioned by RIDA and USAID/Save the Children.

D) Research Assistant at Nepal Health Research Council:

2013-2014

"Adolescent Nutrition Survey" In Nepal commissioned by Nepal Health Research Council.

- Research Assistant for "Environmental Burden of Disease related to Water Sanitation and Hygiene" commissioned by Nepal Health Research Council/WHO 
3. Additional Skills:

- Excellent interpersonal skills like cooperation and coordination.

- Self-motivated and energetic person.

4. Training attended:

- Ability to work independently and in groups.

- K-PHAST-Kentucky Public Health Assistance and Support Team.

- Training workshop on Health Systems Research Proposal Development from 03-08 August, 2014 in Nepal Health Research Council.

- Training workshop on Data Management and Analysis from 21-26 June, 2015 in Nepal Health Research Council.

- Online Training Course (CITI Program) offered by John Hopkins Bloomberg School of Public Health on Basic Human Subjects Research Course.

5. Research Conducted:

- "Adolescent sexual and reproductive health in The Gambia" thesis for MS Epidemiology.

- "Quality of life of women living with HIV/AIDS in Kathmandu" thesis for Post Graduate Diploma in Women's Studies.

- "Situational Analysis of maternal and infant health care services in Kathmandu District" of RECPHEC as a group work in the Post Graduate Diploma in women's studies.

- "Dietary practices of adolescent girls in secondary level students of Biratnagar Sub-metropolitan, Nepal" thesis for Bachelors in Public Health.

6. Research Publication (as co-author):

- Hendrickson, Z., Lohani, S., Underwood, C. What do we mean by empowerment? Exploring the intersection of migration and household gender dynamics in Nepal. Oral presentation presented at the International Council on Women's Health Issues; 9 November 2016; Baltimore, Maryland.

- Zoé Mistrale Hendrickson, Jill Owczarzak, Sandhya Lohani, Bibhu Thapaliya Shrestha \& Carol R. Underwood (2018)The (re)productive work of labour migration: the reproductive lives of women with an absent spouse in the central hill region of Nepal, Culture, Health \& Sexuality, DOI: 10.1080/13691058.2018.1510546

7. Programming Proficiency: SAS, SPSS, Epi Data and End note.

8. Professional Membership: Member of Nepal Health Professional Council. 